\title{
Descriptor-based analytic rating scales
}

\begin{tabular}{|c|l|l|l|}
\hline $\begin{array}{c}\text { Band / } \\
\text { Scoring criteria }\end{array}$ & \multicolumn{1}{|c|}{ Information Completeness } & \multicolumn{1}{c|}{ Fluency of Delivery } & \multicolumn{1}{c|}{ Target Language Quality } \\
\hline $\begin{array}{c}\text { Band 4 } \\
\text { Score range 7-8) }\end{array}$ & $\begin{array}{l}\text { A substantial amount of original messages } \\
\text { delivered (i.e. > 80\%), with a few number of } \\
\text { deviations, inaccuracies, and minor/major } \\
\text { omissions. }\end{array}$ & $\begin{array}{l}\text { Delivery on the whole fluent, containing a few } \\
\text { disfluencies such as (un)filled pauses, long } \\
\text { silence, fillers and/or excessive repairs. }\end{array}$ & $\begin{array}{l}\text { Target language idiomatic and on the whole } \\
\text { correct, with only a few instances of unnatural } \\
\text { expressions and grammatical errors. }\end{array}$ \\
\hline $\begin{array}{c}\text { Band 3 } \\
\text { Score range 5-6) }\end{array}$ & $\begin{array}{l}\text { Majority of original messages delivered (i.e. } \\
\text { 60-70\%), with a small number of deviations, } \\
\text { inaccuracies, and minor/major omissions. }\end{array}$ & $\begin{array}{l}\text { Delivery on the whole generally fluent, } \\
\text { containing a small number of disfluencies. }\end{array}$ & $\begin{array}{l}\text { Target language generally idiomatic and on the } \\
\text { whole mostly correct, with a small amount of } \\
\text { instances of unnatural expressions and } \\
\text { grammatical errors. }\end{array}$ \\
\hline $\begin{array}{c}\text { Band 2 } \\
\text { Score range 3-4) }\end{array}$ & $\begin{array}{l}\text { About half of original messages delivered (i.e. } \\
\text { 40-50\%), with many instances of deviations, } \\
\text { inaccuracies, and minor/major omissions. }\end{array}$ & $\begin{array}{l}\text { Telivery rather fluent. Acceptable, but with } \\
\text { regular disfluencies. } \\
\text { and correct. Acceptable, but contains many } \\
\text { instances of unnatural expressions and } \\
\text { grammatical errors. }\end{array}$ \\
\hline $\begin{array}{c}\text { Band 1 } \\
\text { Score range 1-2) }\end{array}$ & $\begin{array}{l}\text { A small portion of original messages delivered } \\
\text { (i.e. <30\%), with frequent occurrences of } \\
\text { deviations, inaccuracies, and minor/major } \\
\text { omissions, to such a degree that listeners may } \\
\text { doubt the integrity of renditions. }\end{array}$ & $\begin{array}{l}\text { Delivery lacks fluency. It is frequently } \\
\text { hampered by disfluencies, to such a degree that } \\
\text { they may impede comprehension. }\end{array}$ & $\begin{array}{l}\text { Target language stilted, lacking in idiomaticity, } \\
\text { and containing frequent grammatical errors, to } \\
\text { such a degree that it may impede comprehension. }\end{array}$ \\
\hline Proposed score & \multicolumn{2}{l}{} \\
\hline
\end{tabular}

